\title{
Overcoming Social Impacts on Routine Road Maintenance by Involving Community Participation
}

\author{
Yudi Sekaryadi \\ Civil Engineering Department \\ Parahyangan Catholic University \\ Bandung, Indonesia \\ yudisekaryadi65@gmail.com
}

\author{
Wimpy Santosa \\ Civil Engineering Department \\ Parahyangan Catholic University \\ Bandung, Indonesia \\ wimpy.santosa@yahoo.com
}

\author{
Anastasia Caroline Sutandi \\ Civil Engineering Department \\ Parahyangan Catholic University \\ Bandung, Indonesia \\ caroline@unpar.ac.id
}

\begin{abstract}
Routine maintenance by involving the community is needed to overcome the social impact of routine road maintenance. Some of the variables that influence this are the level of community participation, budget and material participation, community institutions, road damage, method of implementation, material, labor, traffic factors, and budget allocation. Structural Equation Modeling analysis method is used to analyze the effect of variable significance. Case studies were carried out in the districts of Cianjur, Bandung, Subang, Purwakarta, Sumedang, Garut, Ciamis, Tasikmalaya, Cirebon, Majalengka and Indramayu. The results of the evaluation of implementation in twenty roads in West Java are in the good, and medium categories. The most influential variables are community participation in village planning, shoulder damage, and labor qualifications. For this reason, it is necessary to carry out routine road maintenance methods by involving community participation, with stages: program determination, maintenance surveys, compilation of activities, selection of types of work, submission of jobs and budgets from the Government to the community, operational cooperation between the Government and villages, village planning meetings prior to implementation, the implementation of routine road maintenance, priority maintenance of the shoulder of the road and increasing workforce capacity.
\end{abstract}

Keywords: social impact, routine maintenance, community participation, West Java, Indonesia

\section{INTRODUCTION}

Transportation can improve connectivity between regions, connectivity can help people to increase their income through greater productivity. Connectivity can improve the economy of the community, but infer social impacts for people who are dealing directly with transportation infrastructure [1]. The social impact of transportation, according to [2] is more to the environmental impacts that occur in the community, such as air quality, noise, water quality, and footprint when transportation is a large space consumer when all infrastructure and supporting equipment are considered. Transportation and connectivity directly or indirectly provide many benefits for many people, while a lot of literature the social impact on the development of transportation facilities and infrastructure including the reduction in people's livelihoods, as well as in the construction of public roads as part of the ground transportation infrastructure [3].

Public roads are roads that are under the jurisdiction and are managed by public authorities and are open to public travel. Public roads include highways, roads, bridges, and roads under the jurisdiction of the state or company district or city of the country for vehicle travel needs [4]. Public roads are roads intended for public traffic. By following under administration and budgeting authority, public roads are divided into roads managed by the Government and roads managed by the Village [5].

Routine maintenance managed by the Government has not yet been fully benefited by residents along the road. Therefore, to reduce the social impact felt by the community along the road, a method of implementing road maintenance is needed by developing potential sources that can increase income for the community along the road. One potential that can be developed is to carry out operational cooperation in road maintenance between the Government and the community.

Problems in road maintenance, that in the project of road improvement and periodic maintenance, maintenance is carried out by the contractor. The most possible work is routine maintenance of roads carried out throughout the year and carried out by self-management methods. Therefore the purpose of this paper is: 1) identifying routine road maintenance and community participation, 2) evaluate routine maintenance and community participation, and 3 ) developing routine road maintenance methods by including community participation.

\section{MATERIAL AND METHOD}

\section{A. Road Routine Maintenance and Community Participation}

Routine road maintenance is the activity of caring for and repairing the damage that occurs in on-road sections with good service conditions. Roads with good service conditions are road segments with good or moderate conditions according to the planned age that are calculated and follow certain standards [6]. Routine maintenance, consisting of small-scale work carried out regularly, aims to ensure the daily feasibility and safety of existing roads in the short term and to prevent premature road damage. The frequency of activities varies but is generally a week to once a month [7].

Routine maintenance is needed continuously on every road, regardless of technical characteristics or traffic volume. Routine maintenance activities are usually small-scale, widespread, and often carried out using manual labor. 
Routine maintenance needs can largely be estimated and scheduled at certain times of the year [8]. Routine maintenance on public roads is carried out in stages, namely: 1) establish routine road maintenance programs, based on the characteristics of road damage, 2) routine maintenance survey on-road sections that have been determined for routine road maintenance programs, 3) compile a list of routine maintenance activities, which include road damage matrices and repair methods, and 4) describe routine maintenance activities to be the need for tools, materials, and wages [9].

Implementation of routine road maintenance by involving the community requires awareness and participation from the community. Community awareness and participation in development activities is not a new concept, the concept has gained recognition as an important requirement for the success of all development projects [10]. The benefits of community participation in development projects include reducing costs, adding additional human resources and realizing better implementation than planned targets. In addition to the emergence of a sense of ownership and responsibility from the community [11]. Participation can be interpreted as a form of role with or active or proactive participation in an activity. Participation is a process that allows for better interaction between stakeholders so that agreements and innovative actions are more likely to be realized from the community [12].

In the development process, [13] said that community participation is the involvement and involvement of community members in the development, including activities in the planning and implementation. Community participation has a very important meaning to encourage development processes that are more directed and by following under community needs. According to [14], the community has a very important meaning in development, namely: 1) is a tool to obtain information on the conditions, needs and attitudes of the community, 2) the community will trust the development project more if they feel involved in the planning and implementation process, and 3) participation is a form of democracy.

The arrangement of road administration aims to realize the role or participation of the community in road administration. Participation means that the community has the right to 1) provide input to the Government in the regulation, guidance, construction and supervision of roads, 2) participate in the implementation of the road, 3) obtaining benefits from the operation of the road by following under the specified minimum service standards, 4) obtain information about the operation of the road, 5) obtain proper compensation due to mistakes in road construction, and 6) filed a lawsuit with the court for losses resulting from road construction $[15,16]$.

\section{B. Research Methods}

The problem of social aspects in transportation activities, namely the social impact in the operation of the road. For this reason, research was carried out on the development of routine road maintenance methods by including community participation. This research is to reduce the social impact of managing roads. The research method carried out is a qualitative method, because in terms of reality are holistic, dynamic, the relationship between reciprocal and interactive variables. While the role of values is tied to the values that will be brought by researchers and data sources [17].

TABLE I. THE LOCATION OF THE ROAD SECTIONS

\begin{tabular}{|l|l|l|c|c|l|}
\hline No. & \multicolumn{1}{|c|}{ Road Name } & \multicolumn{1}{c|}{$\begin{array}{c}\text { Location } \\
\text { (district) }\end{array}$} & $\begin{array}{c}\text { Length } \\
(\mathbf{k m})\end{array}$ & $\begin{array}{c}\text { Traffic Volume } \\
\text { (pcu) }\end{array}$ & $\begin{array}{c}\text { Road } \\
\text { Function }\end{array}$ \\
\hline 1 & Sp3. Perintis Kemerdekaan - Cibeber & Cianjur & 10,56 & 12.170 & PC 2 \\
\hline 2 & Cibeber - Sukanagara & Cianjur & 26,12 & 4.945 & PC 2 \\
\hline 3 & Cileungsi - Cibeet & Bogor & 44,58 & 23.010 & PC 1 \\
\hline 4 & Sukabumi - Cikembar & Sukabumi & 9,72 & 10.379 & PC 2 \\
\hline 5 & Sukabumi - Sagaranten & Sukabumi & 46,42 & 4.371 & PC 2 \\
\hline 6 & Soreang - Ciwidey & Bandung & 7,64 & 6.888 & PC 2 \\
\hline 7 & Banjaran - Pangalengan & Bandung & 20,39 & 10.327 & PC 1 \\
\hline 8 & Cimareme - Batujajar & Bandung & 3,56 & 13.821 & PC 2 \\
\hline 9 & Batujajar - Soreang & Bandung & 11,67 & 9.506 & PC 2 \\
\hline 10 & Subang - Batas Bandung & Subang & 26,96 & 13.224 & PC 1 \\
\hline 11 & Sadang - Batas Purwakarta & Purwakarta & 12,24 & 16.732 & PC 2 \\
\hline 12 & Sumedang - Cikaramas (Subang) & Sumedang & 20,91 & 3.735 & PC 2 \\
\hline 13 & Leles - Cijapati & Garut & 8,60 & $5.737,95$ & PC 3 \\
\hline 14 & Kadungora - Cibatu - Sasakbeusi & Garut & 19,82 & $2.296,08$ & PC 3 \\
\hline 15 & Ciamis - Kawali & Ciamis & 17,71 & $11.788,67$ & PC 2 \\
\hline 16 & Garut - Tasikmalaya & Tasikmlaya & 24,61 & $9.518,15$ & PC 1 \\
\hline 17 & Cirebon - Batas Kuningan & Cirebon & 12,27 & $17.505,57$ & PC 1 \\
\hline 18 & Sumber - Mandirancan & Cirebon & 19,11 & 11.244 .34 & PC 2 \\
\hline 19 & Kadipaten - Batas Indramayu & Majalengka & 22,94 & $10.775,20$ & PC 3 \\
\hline 20 & Karangampel - Jatibarang & Indramayu & 17,11 & $0.817,31$ & PC 1 \\
\hline
\end{tabular}




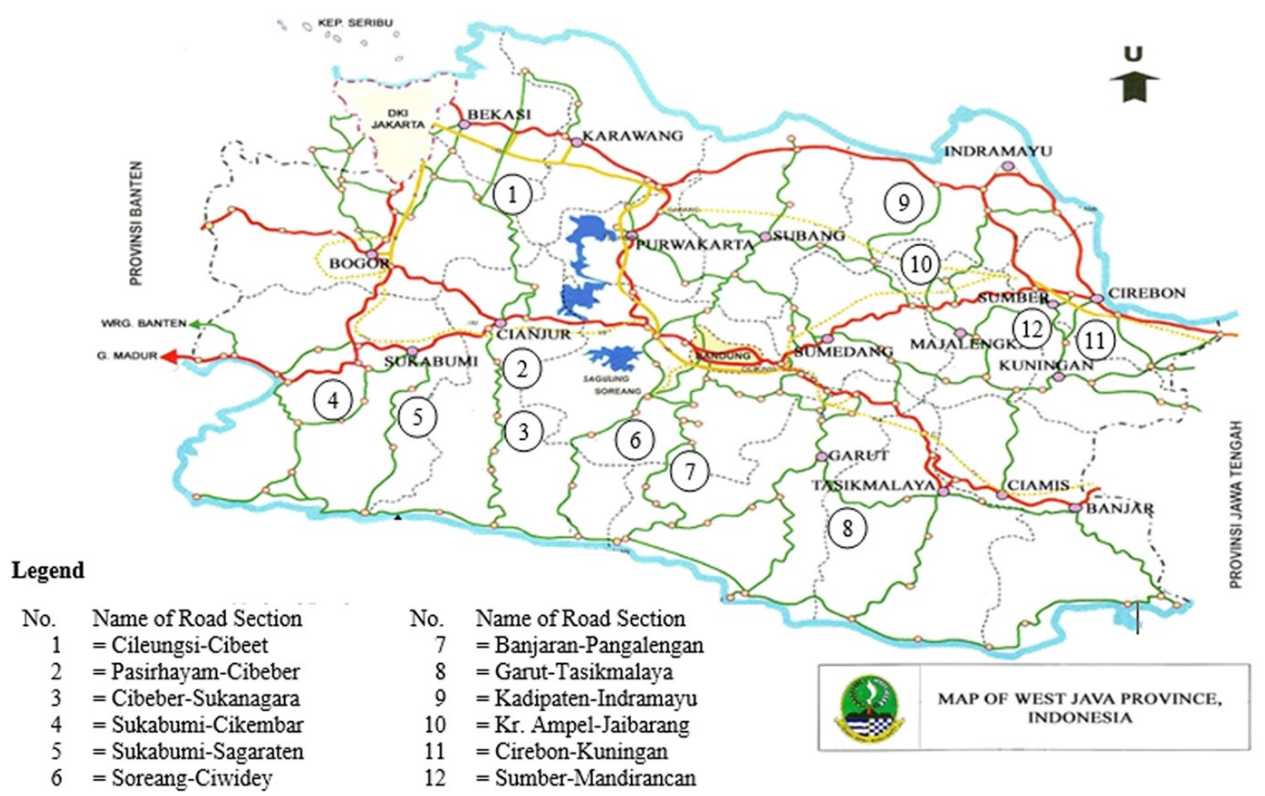

Fig. 1. Research Locations.

The location of the study was conducted on 20 provincial road sections spread across 9 regencies in West Java. The selection of research sites is determined based on, as follows: 1) the road is a primary collector (PC), 2) inter-regency road, 3) high traffic volume, 4) adequate road length, and 5) roads outside the city. The location of the road sections are presented in TABLE I, while the map of the research road sections in Fig. 1.

The next research step is to determine the research variables. Variables are constructs or properties to be learned. Variables can also be said to be a trait drawn from a different value [18]. To measure the research variables, a research instrument or research indicator is created. A research instrument is a tool used to measure the observed natural and social phenomena and the number of research instruments depends on the number of research variables [17].

Based on the results of the study, the variables of community participation consisted of 1) the level of community participation, 2) community budget or material contributions, and 3) community participation institutions. While routine road maintenance variables consist of 1) road damage variable, 2) the method of implementation, 3) material, 4) equipment, 5) labor, 6) traffic factors, and 7) budget allocation.

Evaluate community participation and routine road maintenance based on variables determined, using a Likert scale, namely: a score of 5 categories very well; score 4 in the good category; a score of 3 in the moderate or sufficient category; score 2 bad category; and score 1 category is very bad. The research data of each variable was obtained through a questionnaire from respondents. Determination of the number of respondents, using the method of Isaac and Michael with an error rate of $5 \%$. The Respondents are: 1) Bina Marga Service and Spatial Planning of West Java
Province, 2) Provincial Road Management Technical Implementation Unit, 3) West Java Province Community and Village Government Empowerment Service (DPMPD), 4) District DPMPD, 5) Subdistrict elements, 6) Village elements, and 7) Village Consultative Body (BPD).

Furthermore, to analyze the variables that affect the implementation of routine maintenance of provincial roads and community participation, the Structural Equation Modeling (SEM) method is used using smart PLS software version 3.0. Stages of analysis are the Preparation of the Research Model, Evaluation of the Measurement Model (Outer model) by looking at the results of the Indicator Validity (Convergent Validity), Reliability Construct (Discriminant Validity), and Evaluation of Structural Models [19].

\section{RESULTS AND DISCUSSION}

\section{A. Data Analysis}

The implementation of routine maintenance of provincial roads by including community participation is influenced by several variables. Evaluation is done based on a questionnaire from the respondent. The results of the evaluation of each variable and indicator variables are presented in TABLE II.

From TABLE II it is known that in general the results of evaluation of community participation in village development on 20 provincial roads have a score of more than 3 in the medium and good category, except for the presence and material assistance of the community in village planning meetings which have a score of less than 2 in the category less. Institutional community participation based on a questionnaire, as many as $72 \%$ of respondents agreed to choose the form of institutionalization with operational cooperation between the Government and the community. 
The result of the selection of respondents, the chosen form of community institution is a contract of cooperation between the Provincial Government and the Village Government. The results of evaluating the implementation of routine maintenance of provincial roads, in general have a score of more than 3 in the medium and good categories, except for workers whose certificates are rated poor because the number of provincial routine maintenance workers who have a level 3 skilled labor certificate is only one to two people in 1 unit of labor.

TABLE II. THE IMPLEMENTATION OF COMMUNITY PARTICIPATION AND ROAD ROUTINE MAINTENANCE

\begin{tabular}{|c|c|c|c|c|}
\hline No. & Variables & Score & Indicator Variables & Score \\
\hline 1. & $\begin{array}{l}\text { Level of Community } \\
\text { Participation }\end{array}$ & 3,27 & $\begin{array}{l}\text { a. Community attendance in planning } \\
\text { b. Community attendance during implementation } \\
\text { c. Community attendance for maintenance }\end{array}$ & $\begin{array}{l}3,48 \\
4,06 \\
2,26\end{array}$ \\
\hline 2. & $\begin{array}{l}\text { Budgeting Material } \\
\text { Participation }\end{array}$ & 2,93 & $\begin{array}{l}\text { a. participation in planning activities } \\
\text { b. participation for implementation activities } \\
\text { c. participation for maintenance activities }\end{array}$ & $\begin{array}{l}3,40 \\
3,32 \\
2,07\end{array}$ \\
\hline 3. & Community Institution & 3,38 & $\begin{array}{l}\text { a. Government and village cooperation } \\
\text { b. Government and community organizations coop } \\
\text { c. Government and community groups cooperation }\end{array}$ & $\begin{array}{l}4,03 \\
2,93 \\
3,19\end{array}$ \\
\hline 4. & Traffic Factors & 3,87 & $\begin{array}{l}\text { a. Traffic volume } \\
\text { b. Road Capacity } \\
\text { c. Weight Mixing }\end{array}$ & $\begin{array}{l}3,75 \\
3,60 \\
4,25\end{array}$ \\
\hline 5. & Road damage & 3,18 & $\begin{array}{l}\text { a. Road pavement conditions } \\
\text { b. Road shoulder condition } \\
\text { c. Road drainage conditions } \\
\text { d. Slope condition }\end{array}$ & $\begin{array}{l}3,75 \\
3,20 \\
2,75 \\
3,00\end{array}$ \\
\hline 6. & Implementation Method & 3,44 & $\begin{array}{l}\text { a. Pavement maintenance method } \\
\text { b. Shoulder maintenance method } \\
\text { c. Drainage maintenance method } \\
\text { d. Slope maintenance method }\end{array}$ & $\begin{array}{l}4,15 \\
3,60 \\
2,95 \\
3,05\end{array}$ \\
\hline 7. & Material & 3,63 & $\begin{array}{l}\text { a. Material type as needed } \\
\text { b. Material volume as needed } \\
\text { c. Material quality according to specifications }\end{array}$ & $\begin{array}{l}4,05 \\
3,95 \\
2,90 \\
\end{array}$ \\
\hline 8. & Equipment & 3,08 & $\begin{array}{l}\text { a. Equipment type } \\
\text { b. Equipment capacity } \\
\text { c. Number of equipment }\end{array}$ & $\begin{array}{l}3,10 \\
3,10 \\
3,00\end{array}$ \\
\hline 9. & Labor & 2,57 & $\begin{array}{l}\text { a. Labor Number } \\
\text { b. Labor certification } \\
\text { c. Workforce experience }\end{array}$ & $\begin{array}{l}4,85 \\
4,80 \\
1,65\end{array}$ \\
\hline 10. & Budget Allocation & 3,90 & $\begin{array}{l}\text { a. Availability of sufficient budget } \\
\text { b. The accuracy of budget disbursement }\end{array}$ & $\begin{array}{l}4,50 \\
3,30 \\
\end{array}$ \\
\hline
\end{tabular}

Analysis of the variables that affect community participation and routine maintenance of the province road using the SEM method with the design of the research model as in Fig. 2. Variables are declared to have a significant effect if they have a Statistical $\mathrm{T}$ value of more than 1.96 and a $\mathrm{P}$ value of less than 0.05 or have a confidence level of more than $95 \%$ and a significance level of less than $5 \%$. The results of the analysis are presented in TABLE III.
TABLE III. Result OF ANALysis OF SigNificANCE OF VARIABLES

\begin{tabular}{|l|l|l|l|l|l|}
\hline \multicolumn{1}{|c|}{ Variable } & $\begin{array}{c}\text { Variable } \\
\text { Indicators }\end{array}$ & $\begin{array}{c}\text { Sample } \\
\text { Mean }\end{array}$ & $\begin{array}{c}\text { Standard } \\
\text { Deviation }\end{array}$ & $\begin{array}{c}\text { T } \\
\text { Statistic }\end{array}$ & $\begin{array}{c}\text { P } \\
\text { Values }\end{array}$ \\
\hline $\begin{array}{l}\text { Level of } \\
\text { community } \\
\text { participation }\end{array}$ & $\begin{array}{l}\text { Attendance } \\
\text { at village } \\
\text { planning } \\
\text { meetings }\end{array}$ & 0.947 & 0.102 & 9.732 & 0.000 \\
\hline $\begin{array}{l}\text { Community } \\
\text { budgeting } \\
\text { or material } \\
\text { participation }\end{array}$ & $\begin{array}{l}\text { Material } \\
\text { participation } \\
\text { in village } \\
\text { planning } \\
\text { deliberations }\end{array}$ & 0.951 & 0.101 & 9.832 & 0.000 \\
\hline $\begin{array}{l}\text { Road } \\
\text { damage }\end{array}$ & $\begin{array}{l}\text { Road } \\
\text { shoulder } \\
\text { condition }\end{array}$ & 0.609 & 0.418 & 2.173 & 0.030 \\
\hline Labor & $\begin{array}{l}\text { Labor } \\
\text { certification }\end{array}$ & 0.951 & 0.101 & 2.076 & 0.038 \\
\hline
\end{tabular}




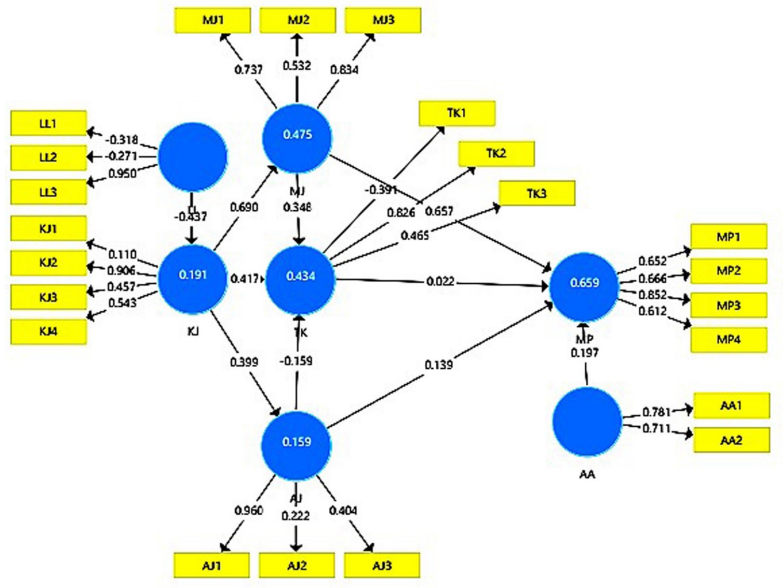

Fig. 2. Designing the Research Model.

\section{B. Discussion of Research Result}

Routine maintenance is carried out on the specified road sections for routine maintenance. To reduce the social impact that occurs on routine road maintenance work, operational cooperation is conducted between the Government and the community. The flow of routine road maintenance programs by including community participation is presented in Fig. 3 with several stages, namely:

1. The first stage establishes a routine road maintenance program, based on the characteristics of road damage.
2. The second stage conducts routine maintenance surveys on the road sections that have been designated for routine road maintenance programs.

3. The third stage compiles a list of routine maintenance activities, which includes road damage matrices and repair methods.

4. The fourth stage selecting the type of routine maintenance work is divided into simple work and not simply work.

5. The fifth stage submits routine road maintenance work and its budget from the Government to the community.

6. The sixth stage of operational cooperation between the Government and the Village.

7. The seventh stage conducting village planning meetings before the maintenance is carried out. The result of the SEM method of community participation in the presence and contribution of the community in village planning meetings.

8. In the eighth stage, carry out routine road maintenance. Road maintenance work consists of types and components of work.

9. The ninth stage is to prioritize the type of work, namely road shoulder maintenance. The results of the analysis by the SEM method that influence variables are damage to the shoulder of the road.

10. Tenth stage, prioritizing the improvement of work components. The results of the analysis by the SEM method of influential variables are labor certification.

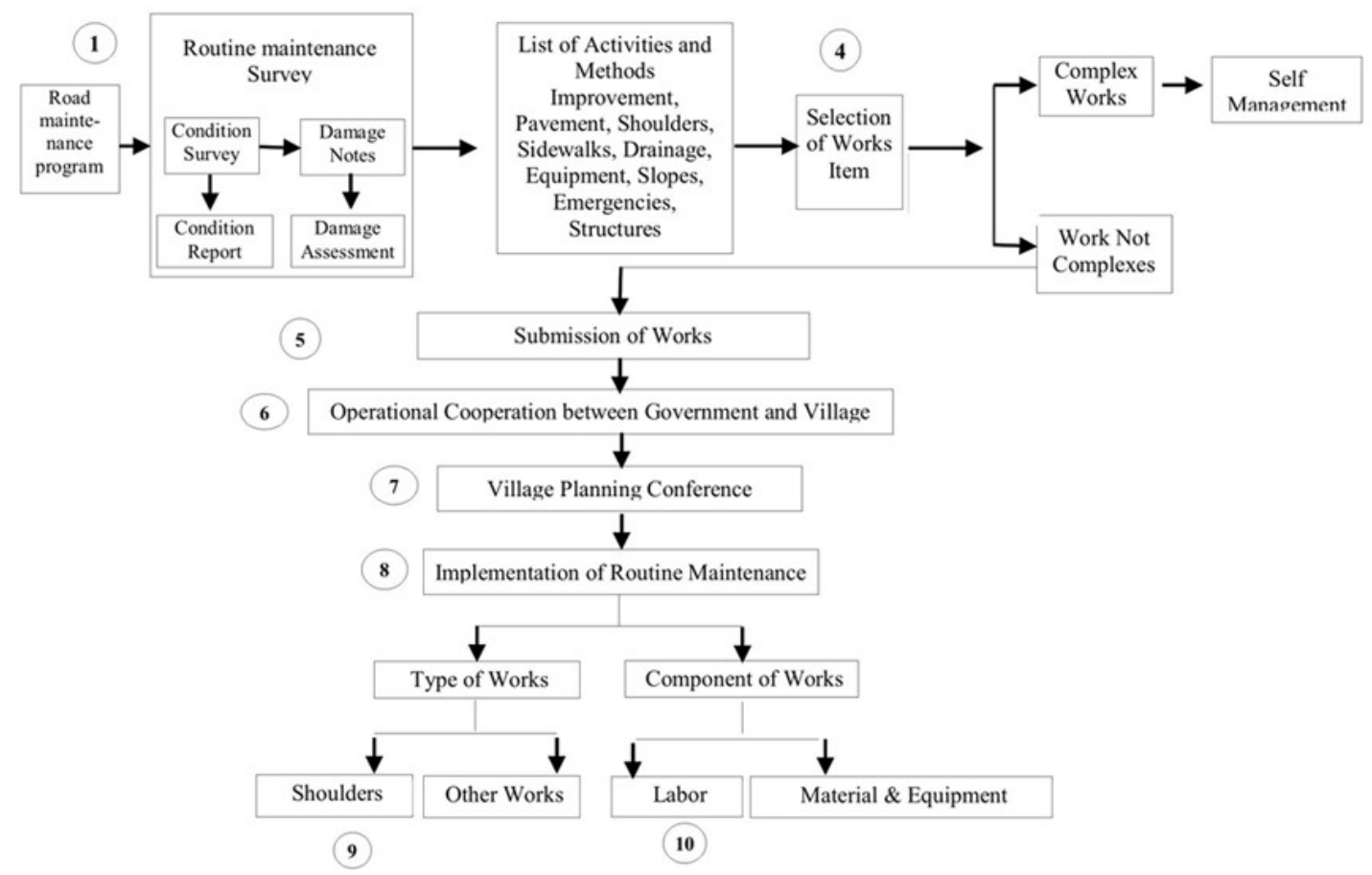

Fig. 3. Flowchart of Routine Road Maintenance Methods by Including Community Participation. 


\section{CONCLUSIONS}

To reduce the social impact felt by the community along the road, a method of implementing road maintenance is needed by developing another potential source, namely operational cooperation in road maintenance between the Government and the community. The results of evaluating the implementation of routine maintenance of provincial roads and community participation in village development on 20 provincial roads have a score of more than 3 with good and very good conditions.

The results of the analysis using the SEM Method are to the 10 stages as follows 1) establishment of a routine road maintenance program, 2) routine maintenance surveys, 3) compile a list of routine maintenance activities, 4) selection of types of routine maintenance work, 5) hand over routine maintenance work for provincial roads and budgets from the Government to the community, 6) operational cooperation between the Government and the Village, 7) village planning deliberations before implementation, 8) routine road maintenance, 9) prioritizing maintenance of the shoulder, and 10) priorities for improving workforce qualifications.

\section{REFERENCES}

[1] Mathew, V.T., Role of Transportation in Society, Lecture Notes in Transportation System Engineering, Civil Engineering, ITB, Bandung, 2009.

[2] Rodrigue P.J., The Geography of Transport Systems, New York: Routledge, 2017.

[3] Norman K, Social Dimensions of Transport - a resource for Social impact appraisals, Department for International Development, UK, 2013.

[4] United States Department of Transportation, Proposed and Final Federal Regulations from the Department of Transportation, USA, 2014.
[5] The Republic of Indonesia, law number 38 the year 2004 about Road, Jakarta, 2004.

[6] The Republic of Indonesia, regulation of the Ministry of Public Works number 13/PRT/M/2011 about Procedures for Road Maintenance, Surveillance, Jakarta, 2011.

[7] Burningham, S, and Stankevich, N., Why the road maintenance is important, how to do it, The World Bank, Washington, DC Transport Note No. TRN-4 June/2005.

[8] Ministry of Rural Development Government of India, Rural Road Maintenance Training Modules for Field Engineers, October, 2015.

[9] The Republic of Indonesia, Decree of the Ministry of Public Works number $001 / \mathrm{T} / \mathrm{Bt} / 1995$ about the routine maintenance manual for national and provincial roads, Jakarta, 1995.

[10] Nour, A.M., CACP, and Approach for Sustainable Urban Development in Egypt, Journal of Sustainable Development, Vol. 4, No. 1, pp. 79-91, 2011.

[11] Moser, C.O.N., "Approaches to Community Participation in Urban Development Programs in Third World Countries", In Bamberger, ed. Readings in Community Participation, Washington, DC: World Bank, 1987.

[12] Solekhan, M, Organizing Community-Based Village Government, Malang, 2014.

[13] Adisasmita, Rahardjo, Rural, and Urban Development, Yogyakarta, Graha Ilmu, 2006.

[14] Conyers, Diana, and, Hills, Peter, An Introduction to Development Planning in Third World, New York, Brisbane, 1990.

[15] The Republic of Indonesia, regulation of the Ministry of Public Works of the Republic of Indonesia number 01/PRT/M/2012 concerning Guidelines for the Role of the Community in Operation of the Road, Jakarta, 2012.

[16] The Republic of Indonesia, regulation of the Republic of Indonesia number 34 the year 2006 about Road, Jakarta, 2006.

[17] Sugiyono, Research Methods, Quantitative, Qualitative and R\&D, Alfabeta Publisher, Bandung, 2017.

[18] Kerlinger, N., dan Fred, Behavioral Research Principles, Gajah Mada University Press, Yogyakarta, 2006.

[19] Haryono, S., Structural Equation (SEM) Modeling Method for Management Research of AMOS LISREL PLS, Luxima Metro Media Publisher, Jakarta, 2017. 